\title{
The research of the schemes of regional distributed energy system
}

\author{
LU Jin ${ }^{1}$, YAN Tao ${ }^{1, a}$, CAI Wen ${ }^{1}$,Yang Hong-yan ${ }^{2}$, WAN Zhong-hai ${ }^{1}$ \\ ${ }^{1}$ State Grid JiangXi Electric Power Research Institute, Nanchang 330096,Jiangxi Province,China \\ ${ }^{2}$ Shanghai Pengken Energy Technology Co.LTD, Shanghai 200090,China
}

\begin{abstract}
The distributed energy generation system is one of the main forms of the second-generation energy system currently. Three kinds of viable schemas of distributed energy supply system for nine users of the small region heat of Yangpu area combining with urban heating were proposed in this thesis, in which the gas turbines were selected. By analyzing the heat economy and pollutant emissions, the advantages and disadvantages of each schema were found out and the relatively better one was selected ultimately. Finally, some possible development trends and the prospects of the distributing energy supply system were also related and some complementary proposals were to table for some aspects of the system.
\end{abstract}

\section{Introduction}

Distributed energy system is a kind of circulatory energy supply system with a lot of advantages, which is a kind of economical energy supply system, with the less emission of pollutants in the production process, and more efficient energy saving because of the gradient utilization of energy. Moreover, the distributed energy system has practical significance for ensuring power supply, It can not only make up for the shortcomings of the power grid in terms of safety and stability, but also ensure the power supply of users when accidents happen, such as earthquakes, storms, human destruction, wars and other accidents. The distributed energy system accords with the principle of "reduction, reuse" and "minimizing resource consumption and environmental cost" in circular economy, which is widely recognized in today's society.

\section{The proposal of system scheme}

According to the heat consumption statistics of nine heat consumers in the small area of Yangpu District, this paper has estimated the maximum system power $22.2 \mathrm{MW}$ and minimum system total power $14.1 \mathrm{MW}$ and proposed three feasible schemes.

\subsection{Scheme one: using three miniaturized gasturbines}

The scheme uses two Mars90 gasturbines of sola and a Taurus60 gasturbine, and the corresponding thermodynamic calculation results are obtained, such as table 1 .

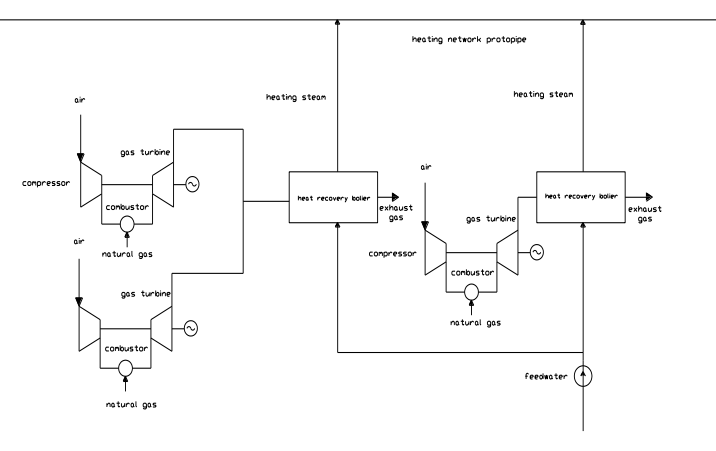

Figure 1 scheme one system diagram

Table 1 system calculation results of scheme one

\begin{tabular}{|c|c|c|c|c|}
\hline 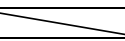 & program & symbol & unit & figure \\
\hline \multirow[t]{5}{*}{$\begin{array}{l}\text { MAR90 } \\
\text { gasturbine }\end{array}$} & $\begin{array}{l}\text { Compressor } \\
\text { actual exit } \\
\text { temperature }\end{array}$ & $\mathrm{T}_{2}^{*}$ & $\mathrm{~K}$ & 696.03 \\
\hline & $\begin{array}{l}\text { Compression } \\
\text { work }\end{array}$ & wc & $\mathrm{kJ} / \mathrm{kg}$ & 425.38 \\
\hline & $\begin{array}{c}\text { Gas initial } \\
\text { temperature }\end{array}$ & $\mathrm{T}_{3}^{*}$ & $\mathrm{~K}$ & 1290 \\
\hline & Expansion work & $\mathrm{w}_{\mathrm{T}}$ & $\mathrm{kJ} / \mathrm{kg}$ & 658.77 \\
\hline & $\begin{array}{c}\text { Thermal } \\
\text { efficiency }\end{array}$ & $\eta_{\mathrm{gt}}$ & $\%$ & 32.4 \\
\hline \multirow{5}{*}{$\begin{array}{l}\text { Taurus60 } \\
\text { gasturbine }\end{array}$} & $\begin{array}{l}\text { Compressor } \\
\text { actual exit } \\
\text { temperature }\end{array}$ & $\mathrm{T}_{2}^{*}$ & K & 696.03 \\
\hline & $\begin{array}{c}\text { Compression } \\
\text { work }\end{array}$ & wc & $\mathrm{kJ} / \mathrm{kg}$ & 425.38 \\
\hline & $\begin{array}{c}\text { Gas initial } \\
\text { temperature }\end{array}$ & $\mathrm{T}_{3}^{*}$ & K & 1316 \\
\hline & Expansion work & $\mathrm{w}_{\mathrm{T}}$ & $\mathrm{kJ} / \mathrm{kg}$ & 660.72 \\
\hline & $\begin{array}{c}\text { Thermal } \\
\text { efficiency }\end{array}$ & $\eta_{\mathrm{gt}}$ & $\%$ & 31.2 \\
\hline \multirow{2}{*}{$\begin{array}{l}\text { Heat } \\
\text { recovery } \\
\text { boiler }\end{array}$} & $\begin{array}{c}\text { Steam } \\
\text { generation of } \\
\text { heat recovery } \\
\text { boiler } \\
\end{array}$ & $\mathrm{m}_{3}$ & $\mathrm{t} / \mathrm{h}$ & 48.23 \\
\hline & $\begin{array}{l}\text { Efficiency of } \\
\text { heat recovery } \\
\text { boiler }\end{array}$ & $\eta_{y r}$ & $\%$ & 76.82 \\
\hline
\end{tabular}

\footnotetext{
* Corresponding author: ${ }^{a}$ cherrymanyan@ $@$ sina.com
} 


\begin{tabular}{|c|c|c|c|c|}
\hline \multirow{3}{*}{ system } & Total efficiency & $\eta_{\text {总 }}$ & $\%$ & 84.36 \\
\cline { 2 - 5 } & $\begin{array}{c}\text { Sulfur dioxide } \\
\text { emissions }\end{array}$ & $\mathrm{m}_{\mathrm{s} 02}$ & $\mathrm{t} / \mathrm{year}$ & 0175 \\
\cline { 2 - 5 } & $\begin{array}{c}\text { Carbon dioxide } \\
\text { emissions }\end{array}$ & $\mathrm{m}_{\mathrm{co} 2}$ & $10^{4} \mathrm{t} / \mathrm{year}$ & 6.76 \\
\hline
\end{tabular}

\subsection{Scheme two: using two miniaturized gasturbines}

In scheme two, a heat recovery is used to match two FT8 gasturbines. The corresponding calculation results can be obtained by the thermodynamic calculation, such as table 2 .

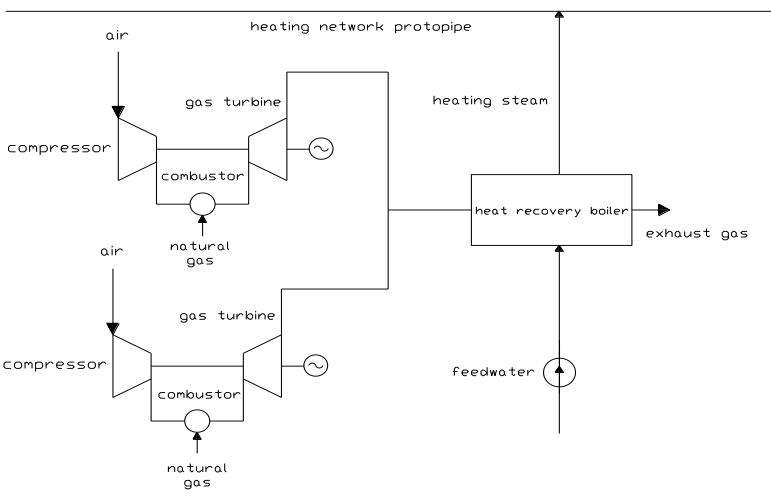

Figure 2 scheme two system diagram

Table 2 system calculation results of scheme two

\begin{tabular}{|c|c|c|c|c|}
\hline & program & symbol & unit & figure \\
\hline \multirow{7}{*}{$\begin{array}{c}\text { FT8 gas } \\
\text { turbine }\end{array}$} & $\begin{array}{c}\text { Compressor } \\
\text { actual exit } \\
\text { temperature }\end{array}$ & $\mathrm{T}^{*}{ }_{2}$ & $\mathrm{~K}$ & 715.17 \\
\cline { 2 - 5 } & $\begin{array}{c}\text { Compression } \\
\text { work }\end{array}$ & $\mathrm{wC}$ & $\mathrm{kJ} / \mathrm{kg}$ & 446.20 \\
\cline { 2 - 5 } & $\begin{array}{c}\text { Gas initial } \\
\text { temperature }\end{array}$ & $\mathrm{T}^{*}{ }_{3}$ & $\mathrm{~K}$ & 1322 \\
\cline { 2 - 5 } & Expansion work & $\mathrm{w}_{\mathrm{T}}$ & $\mathrm{kJ} / \mathrm{kg}$ & 723.50 \\
\cline { 2 - 5 } Heat & $\begin{array}{c}\text { Thermal } \\
\text { efficiency }\end{array}$ & $\eta_{\mathrm{gt}}$ & $\%$ & 37.3 \\
\hline \multirow{3}{*}{ boiler } & $\begin{array}{c}\text { Steam } \\
\text { generation of } \\
\text { heat recovery } \\
\text { boiler }\end{array}$ & $\mathrm{m}_{3}$ & $\mathrm{t} / \mathrm{h}$ & 27.20 \\
\cline { 2 - 5 } & $\begin{array}{c}\text { Efficiency of } \\
\text { heat recovery } \\
\text { boiler }\end{array}$ & $\eta_{\mathrm{yr}}$ & $\%$ & 75.70 \\
\hline \multirow{7}{*}{ system } & $\begin{array}{c}\text { The efficiency } \\
\text { of combined } \\
\text { cycle }\end{array}$ & $\eta_{\text {总 }}$ & $\%$ & 83.9 \\
\cline { 2 - 5 } & $\begin{array}{c}\text { Sulfur dioxide } \\
\text { emissions }\end{array}$ & $\mathrm{m}_{\mathrm{s} 02}$ & $\mathrm{t} / \mathrm{year}$ & 0.11 \\
\cline { 2 - 5 } & $\begin{array}{c}\text { Carbon dioxide } \\
\text { emissions }\end{array}$ & $\mathrm{m}_{\mathrm{co} 2}$ & $10^{4} \mathrm{t} / \mathrm{year}$ & 4.21 \\
\hline
\end{tabular}

\subsection{Scheme three: using one miniaturized gasturbine}

The Scheme three uses one QD168 gasturbine with a heat recovery boiler, The corresponding calculation results can be obtained by the thermodynamic calculation, such as table 3 .

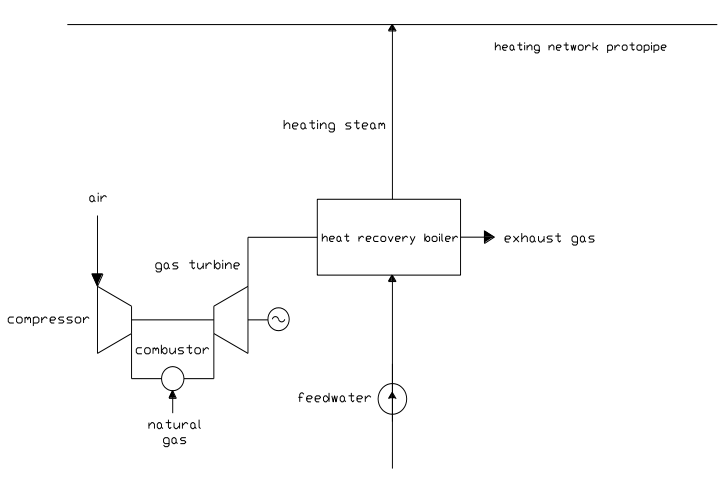

Figure 3 scheme three system diagram

Table 3 system calculation results of scheme three

\begin{tabular}{|c|c|c|c|c|}
\hline 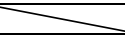 & program & symbol & unit & figure \\
\hline \multirow{5}{*}{$\begin{array}{l}\text { QD168 } \\
\text { gas turbine }\end{array}$} & $\begin{array}{l}\text { Compressor } \\
\text { actual exit } \\
\text { temperature }\end{array}$ & $\mathrm{T}_{2}^{*}$ & $\mathrm{~K}$ & 696.03 \\
\hline & $\begin{array}{c}\text { Compression } \\
\text { work }\end{array}$ & $\mathrm{w}_{\mathrm{C}}$ & $\mathrm{kJ} / \mathrm{kg}$ & 425.38 \\
\hline & $\begin{array}{c}\text { Gas initial } \\
\text { temperature }\end{array}$ & $\mathrm{T}_{3}^{*}$ & $\mathrm{~K}$ & 1316 \\
\hline & Expansion work & WT & $\mathrm{kJ} / \mathrm{kg}$ & 705.24 \\
\hline & $\begin{array}{c}\text { Thermal } \\
\text { efficiency }\end{array}$ & $\eta_{\mathrm{gt}}$ & $\%$ & 37.0 \\
\hline \multirow{2}{*}{$\begin{array}{l}\text { Heat } \\
\text { recovery } \\
\text { boiler }\end{array}$} & $\begin{array}{c}\text { Steam } \\
\text { generation of } \\
\text { heat recovery } \\
\text { boiler }\end{array}$ & $\mathrm{m}_{3}$ & $\mathrm{t} / \mathrm{h}$ & 42.62 \\
\hline & $\begin{array}{l}\text { Efficiency of } \\
\text { heat recovery } \\
\text { boiler }\end{array}$ & $\eta_{\mathrm{yr}}$ & $\%$ & 76.20 \\
\hline \multirow{3}{*}{ system } & $\begin{array}{l}\text { The efficiency } \\
\text { of combined } \\
\text { cycle }\end{array}$ & $\eta_{\text {总 }}$ & $\%$ & 84.3 \\
\hline & $\begin{array}{c}\text { Sulfur dioxide } \\
\text { emissions }\end{array}$ & $\mathrm{m}_{\mathrm{so} 2}$ & t/year & 0.17 \\
\hline & $\begin{array}{c}\text { Carbon dioxide } \\
\text { emissions }\end{array}$ & $\mathrm{m}_{\mathrm{co} 2}$ & $10^{4} \mathrm{t} /$ year & 6.49 \\
\hline
\end{tabular}

\section{Comparison of system schemes}

Based on the results of the three schemes, this paper compares the following four aspects:

\subsection{The adaptability of heat load}

\section{Scheme one:}

The system can stop the Taurus60 gasturbine on January, February, May, June, September and October and can stop one of the two Mars90 gasturbines on July and August. All of the three gasturbines open on the other months. The load is well-adapted, and all of the gasturbines are operated with more than $86 \%$ load.

\section{Scheme two:}

The system can stop one of the two FT8 gasturbines on July and August,both of the two FT8 gasturbines are open on the other months. The low load is fair to middling,but the operation time of the gasturbine is long at low load, most of it is in $60 \% \sim 80 \%$. 


\section{Scheme three:}

The QD168 gasturbine operates with 75\% load except for July and August.

In terms of load adaptability, the scheme one is the best, the scheme three is better than the scheme two.

\subsection{Scheme investment}

As the cost of the heat recovery boiler and sites is less than ten percent of the gasturbine,so it is mainly discussed for gasturbine costs.

\section{Scheme one:}

The cost of sola Taurus is $\$ 434.78 / \mathrm{KW}$, and Mars is $\$ 460.00 / \mathrm{KW}$, with a total cost of 71.78 million RMB.

\section{Scheme two:}

The cost of FT8 is $\$ 429.69 / \mathrm{KW}$, with a total cost of 74.91 million RMB.

\section{Scheme three:}

The cost of QD168 is $\$ 417.65 / \mathrm{KW}$, with a total cost of 95.54 million RMB.

In terms of the investment,the scheme one is relatively small,the scheme two is the middle,the scheme three is the most.

\subsection{Energy supply reliability of gasturbine}

\section{Energy supply reliability of gasturbine of Scheme one:}

$$
A_{1}=1-\left(1-(1-P) \cdot\left(1-a_{1} \cdot a_{3}\right)\right) \cdot\left(1-(1-P) \cdot\left(1-a_{1}\right)\right)
$$

$\mathrm{a}_{1}$ is the malfunction rate of Taurus 60 gasturbine, $\mathrm{a}_{2}$ and $a_{3}$ are the malfunction rates of the two Mars90 gasturbines respectively. (the malfunction rates of the heat recovery boiler is set to a fixed value of $\mathrm{P}$ )

\section{Energy supply reliability of gasturbine of Scheme two:}

$B_{1}=1-(1-P) \cdot\left(1-b_{1} \cdot\right)$

$b_{1}$ is the malfunction rate of the FT8 gasturbine.

\section{Energy supply reliability of gasturbine of Scheme three:}

$C_{1}=(1-P) \cdot\left(1-c_{1} \cdot c_{2} \cdot\right)$

$c_{1}$ and $c_{2}$ are the malfunction rates of the two QD168 gasturbines respectively.

As the malfunction rate of gasturbine is very small,
$\left[1-(1-P) \cdot\left(1-a_{2} \cdot a_{3} \cdot\right)\right] \cdot\left[1-(1-P) \cdot\left(1-a_{2} \cdot\right)\right]$

$<(1-P) \cdot\left(1-c_{1} \cdot c_{2}\right)<(1-P) \cdot\left(1-b_{1}\right)$

Therefore, $\mathrm{A}_{1}>\mathrm{C}_{1}>\mathrm{B}_{1}$, so as to the operation reliability of gasturbine, the scheme one is the best scheme of the three schemes, the scheme three is the middle, and the scheme two is the worstest.

\subsection{Environmental pollution}

The pollution which the schemes of energy supply system bring to the environment is very low,so it is not so much value to compare here. In order to make comparison and analysis, a small boiler scheme is added in this paper.

According to the statistics from China energy network, we know that there will discharge about 2 tons of $\mathrm{CO}_{2}$ and 20 kilograms of $\mathrm{SO}_{2}$ and 15 kilograms of smoke dust and 260 kilograms of ash when consuming one tons of standard coal in production process. The comparison of heat supply in a month is shown in the following table.

Table 4 Comparison of total emission and $\mathrm{CO} 2$ emissions of each scheme in December (tons)

\begin{tabular}{|c|c|c|c|c|}
\hline & $\begin{array}{c}\text { The } \\
\text { scheme } \\
\text { of } \\
\text { small } \\
\text { boiler }\end{array}$ & $\begin{array}{c}\text { scheme } \\
\text { one }\end{array}$ & $\begin{array}{c}\text { scheme } \\
\text { two }\end{array}$ & $\begin{array}{c}\text { scheme } \\
\text { three }\end{array}$ \\
\hline $\mathrm{SO}_{2}$ & 24.04 & $7.81 \times 10^{-3}$ & $8.61 \times 10^{-3}$ & $8.55 \times 10^{-3}$ \\
\hline $\mathrm{CO}_{2}$ & 2404 & 3012 & 3356 & 3270 \\
\hline $\begin{array}{c}\text { Smoke } \\
\text { dust }\end{array}$ & 18.03 & 0 & 0 & 0 \\
\hline ash & 312.52 & 0 & 0 & 0 \\
\hline
\end{tabular}

From the table 4, it can be seen that the smoke dust and ash of the three schemes are zero, and the $\mathrm{SO}_{2}$ emission is also several orders of magnitude less than that of the small boiler scheme.

The only doubt is that the annual emission of $\mathrm{CO}_{2}$ for the scheme of small boiler is less than that of the other three schemes, However, the actual problem is that all the three schemes have power generation but the scheme of small boiler have no power generation. If a clearer comparison is needed, this part of the power must be filled by the power grid. According to preliminary estimates, the scheme of small boiler should be supplemented with about 1,870 tons of $\mathrm{CO}_{2}$, which will make it more $\mathrm{CO}_{2}$ emissions than the other three options. In addition, when users are theoretically the same, pollution emissions are basically the same, and their differences are closely related to the overall efficiency of the system.

\section{Conclusions}

From the above comparative analysis we can see:

The features of scheme one are: (1) Strong heat load adaptability (2) The reliability of Power supply is better (3) Lower initial investment (4) Unavailable to develop potential users 
The features of scheme two are: (1) Power supply reliability is good (2) Poor load adaptability ( 3 ) Potentially hot users can be developed (4) High initial investment

The features of scheme three are: (1) The initial investment is on the middle level (2) Poor reliability of energy supply (3) Poor operation stability

In summary, from the perspective of the entire analysis, scheme one is slightly better than other schemes. Although there are scattered users in the Yangpu area, of which the potential demand for heat is small and will not affect the value of scheme one.

During the study of schemes, the following problems are also founded in this article:

(1) First of all, the accuracy of the heat load.Since only the total amount of steam required by users in the Yangpu area is known in this article and there is no accurate daily or even hourly heat data, only the monthly average heat load energy is used to estimate the heat load. This leads to the fact that the actual maximum heat load may be higher than the calculated value.

(2) Secondly, the issue of Internet access. Due to the small amount of electricity generated by the system, it is very difficult to send the electricity on the grid under the current policy.

(3) Thirdly, the introduction of water resources and gas sources. Water and natural gas consumption are very large. How to find sources of abundant natural gas and ensure the supply of water is also a thorny issue.

(4) Finally, the loss of cold source. After the steam is delivered to the user, the used water is difficult to recover, resulting in a relatively large loss of cold source.

\section{References}

1. Gong Jie,Hua Ben. Journal of Shenyang Institute of Engineering (Natural Science),Distributed energy system: co-generation and co-supply,Vol.1 No.3: 11-15 (2007)

2. Chen xi, Guoqing Wu,Kuifang Wan,Aiguo Liu, YUNNAN ELECTRIC POWER, Some Thoughts on Developing Distributed Energy Supply Technology, Vol.5 No.36: 73-74 (2008)

3. Jianzhong Xu,Sui Jun,Hongguang Jin, Solar Energy, The status and trends of distributed energy systems,No.4: 14-16 (2004)

4. Chengshan WANG,Shouxiang WANG, Automation of Electric Power Systems, Research on Several Problems of Distributed Generation Energy Supply System, No.10: 1-4 (2008)

5. Distributed Energy Resources: Current Landscape and a Roadmap for the Future. Palo Alto,CA,USA:EPRI (2004)

6. Jianhua Yue,Yongbing Li, INNER MONGOLIA ELECTRIC POWER, Application and its Forecast to Combined-system of Cooling: Heating and Power in Home and Foreign,Vol.5 No.26: 1-4 (2008)
7. WADE. World Survey of Decentralized, Energy, (2004)

8. Yiqun Pan,Huangzhi etc. HVAC, Feasibility of applying distributing energy supply system in a new hospital in Shanghai, Vol.2 No.34: 68-72 (2004)

9. Jiao Yonggang, You Zhanping, Hao Changsheng, REFRIGERATION AND AIRCONDITIONING,The technological analysis of distributed energy system for pharmaceutical factory, 77-79 (2008) 